\title{
Population and distribution of some herons in Babakan Rancabayawak, Bandung City, Indonesia
}

\author{
ERRI NOVIAR MEGANTARA ${ }^{1,2,3}$, TEGUH HUSODO ${ }^{1,2,3,}$, JOHAN ISKANDAR $^{1,2,3}$, DEDEN NURJAMAN $^{3}$, \\ SUROSO $^{3}$, SYAHRAS FATHIN AMINUDDIN ${ }^{3}$, ZAMZAM I'LANUL ANWAR ATSAURY ${ }^{3}$, \\ INDRI WULANDARI ${ }^{1,2,3}$, SYA SYA SHANIDA ${ }^{3}$ \\ ${ }^{1}$ Department of Biology, Faculty of Mathematics and Natural Sciences, Universitas Padjadjaran. Jl. Raya Bandung-Sumedang Km 21, Jatinangor, \\ Sumedang 45363, West Java, Indonesia. Tel. +62-22-7796412 ext. 104, Fax. +62-22-7794545, `email: teguhhusodo2@gmail.com \\ ${ }^{2}$ Program of Environmental Science, School of Graduates, Universitas Padjadjaran. J1. Sekeloa, Coblong, Bandung 40134, West Java, Indonesia \\ ${ }^{3}$ Center of Environment and Sustainable Science, Directorate of Research, Community Services and Innovation, Universitas Padjadjaran. Jl. Raya \\ Bandung-Sumedang Km 21, Jatinangor, Sumedang 45363, West Java, Indonesia
}

Manuscript received: 9 November 2021. Revision accepted: 18 November 2021.

\begin{abstract}
Megantara EN, Husodo T, Iskandar J, Nurjaman D, Suroso, Aminuddin SF, Atsaury ZIA, Wulandari I, Shanida SS. 2021. Population and distribution of some herons in Babakan Rancabayawak, Bandung City, Indonesia. Biodiversitas 22: 5389-5396. The Cinambo River flood control channel in the Rancabayawak impacts the decline in the habitat quality of some herons, such as cattle egret [Bubulcus ibis (Linnaeus, 1758)], little egret [Egretta garzetta (Linnaeus, 1766)], and Javan pond-heron [Ardeola speciosa (Horsfield, 1821)]. Besides, many built-up areas due to the urbanization in peri-urban areas also impact habitat quality, such as the loss of plants commonly used as perching and nesting sites. Along with the development of Rancabayawak as a built-up area, it is essential to study the management of those birds. This study aims to reveal: 1) plants used as perching and nesting sites, 2) population size and distribution, and management efforts on B. ibis, E. garzetta, and A. speciosa in Babakan Rancabayawak Hamlet, Gedebage Subdistrict, Bandung, West Java, Indonesia. A mixed-methods approach was applied in this study by calculating the estimated population and bird nests, plant inventory survey, and the installation of the A8 mini GPS. Bambusa vulgaris, Leucaena leucocephala, and Mimosa pigra are plants that are used as perching and nesting sites by B. ibis, E. garzetta, and A. speciosa. The estimated population mean of those birds was 630 individuals, 92 individuals, and 43 individuals, respectively, with the population average of those birds, is 1680 individuals. Three hundred twenty-nine nests (329) were found during the study. Based on distribution mapping, birds moved east and south, covering paddy fields in Rancaekek, Solokanjeruk, and Majalaya within a radius of $12 \mathrm{~km}$. Management efforts can be conducted by not cutting down the plants that become nesting and perching sites and maintaining the wetlands in their habitats.
\end{abstract}

Keywords: Ardeidae, egret, heron, Rancabayawak, freshwater swamp

\section{INTRODUCTION}

Globally, the paddy field has become an essential habitat for aquatic birds, including in Indonesia (Howes et al. 2003), Chine (Lin et al. 2018), and South America (Dias et al. 2014). Although the paddy field is essential habitat for aquatic birds, its ecosystem in many regions has dramatically changed due to conversion to other land use types (Harisa 2016). Iskandar and Iskandar (2020) said that cattle egret [Bubulcus ibis (Linnaeus, 1758)], little egret [Egretta garzetta (Linnaeus, 1766)], and Javan pond-heron [Ardeola speciosa (Horsfield, 1821)] had been recorded for a long time in the Babakan Rancabayawak (Bandung, Indonesia), e.g., paddy field. Pang et al. (2019) said that $E$. garzetta often builds its nests in multi-species heronries. In multi-species heronries, the coexistence of hundreds of breeding birds results in dense nesting and partitioning of the available space.

Iskandar and Iskandar (2020) state that, in early 2002, before the construction of the Cinambo River flood control channel, the paddy fields were still a swamp in Babakan Rancabayawak. Along with the construction of the Cinambo River flood control channel, the paddy fields in
Babakan Rancabayawak have not flooded much anymore. However, the increasing population has led to the transfer of wetlands, e.g., paddy fields and swamps, into residential lands. Even though the paddy field was converted into built-up lands, such as housing in the Babakan Rancabayawak, those birds still survive in the area. A similar condition happened in Greece (Kazantzidis et al. 2013). The wetlands have been exploited and modified according to human needs (crop and animal farming, urban and industrial development, fishing, tourism, etc.), so that those land changes are a serious threat for three heron species, such as the purple heron (Ardea purpurea), the squacco heron (Ardeola ralloides), and the black-crowned night heron (Nycticorax nycticorax).

Heronries are the sources of the breeding population of herons, egrets, and other associated water birds. Heronries play a vital role in the conservation of these birds. For successful conservation and recovery of aquatic bird, an extensive understanding of the eco-biological requirements of these birds are essential ( $\mathrm{Li}$ et al. 2016). The management efforts need to be carried out to preserve the population of birds amidst a large amount of built-up land in Babakan Rancabayawak. It is necessary to protect its 
habitat as a whole. Ecologically, bird habitats include shelter, resting, nesting, and hunting. Based on the introduction, this study aims to reveal: 1) the plants that are commonly used as perching and nesting places of B. ibis, E. garzetta, and A. speciosa; 2) estimation of population size and distribution of B. ibis, E. garzetta, and A. speciosa; and 3) management efforts to maintain the existence of $B$. ibis, E. garzetta, and A. speciosa in Babakan Rancabayawak, Gedebage Subdistrict, West Java.

\section{MATERIALS AND METHODS}

\section{Study area}

This study was conducted in January-March 2018 in Babakan Rancabayawak Hamlet, Cisaranten Kidul Village, Gedebage Subdistrict, Bandung City, West Java, Indonesia (Figure 1). Babakan Rancabayawak consists of several land cover types: riparian, shrubs, settlements, and home gardens. For assessment of bird population size, We divided the sampling area into three zones. Zone A consists of common bamboo (Bambusa vulgaris), candlenut (Aleurites moluccanus), and wild tamarind (Leucaena leucocephala). Zone B consists of B. vulgaris. Zone $\mathrm{C}$ consists of B. vulgaris, L. leucocephala, banana (Musa sp.), and giant sensitive plant (Mimosa pigra).

\section{Procedures}

Data collection was conducted using qualitative approaches, including bird population size, bird's nest observation, population distribution, vegetation, and prey.
The birds studied were B. ibis, E. garzetta, and A. speciosa of the family Ardeidae.

\section{Bird population size}

Data were collected by direct counting using the "inout" technique (Iskandar 2017). The population size was assessed for 21 days by directly counting the population that comes out (out) and enter (in) to the nest in the $B$. vulgaris, as well as the birds that remain in or in around the bird's nest (Iskandar 2017). The counting (out) was conducted at 05.15 - 07.00 a.m. and continued until no more birds came out of the $B$. vulgaris. Meanwhile, the counting (in) was conducted at 04.00 - 06.00 p.m. and continued until no more birds returned to the B. vulgaris. When We counted birds that returned to the nest (in the evening), We did not count on birds that came out of the nest or vice versa to minimize multiple counting. The parameters observed in the calculation of population size, including bird species, the number of individuals. The direction of movement of each individual (in-out) was observed based on the four cardinal directions. Bird identification referred to the field guidebook of bird species in nature (Bibby et al. 1992; MacKinnon et al. 1992; Howes et al. 2003).

\section{Vegetation types}

An inventory survey was conducted to determine the vegetation type and plant composition in the bird's habitat. In addition, We recorded the plant species used as a nesting and resting place and place for hunting prey.
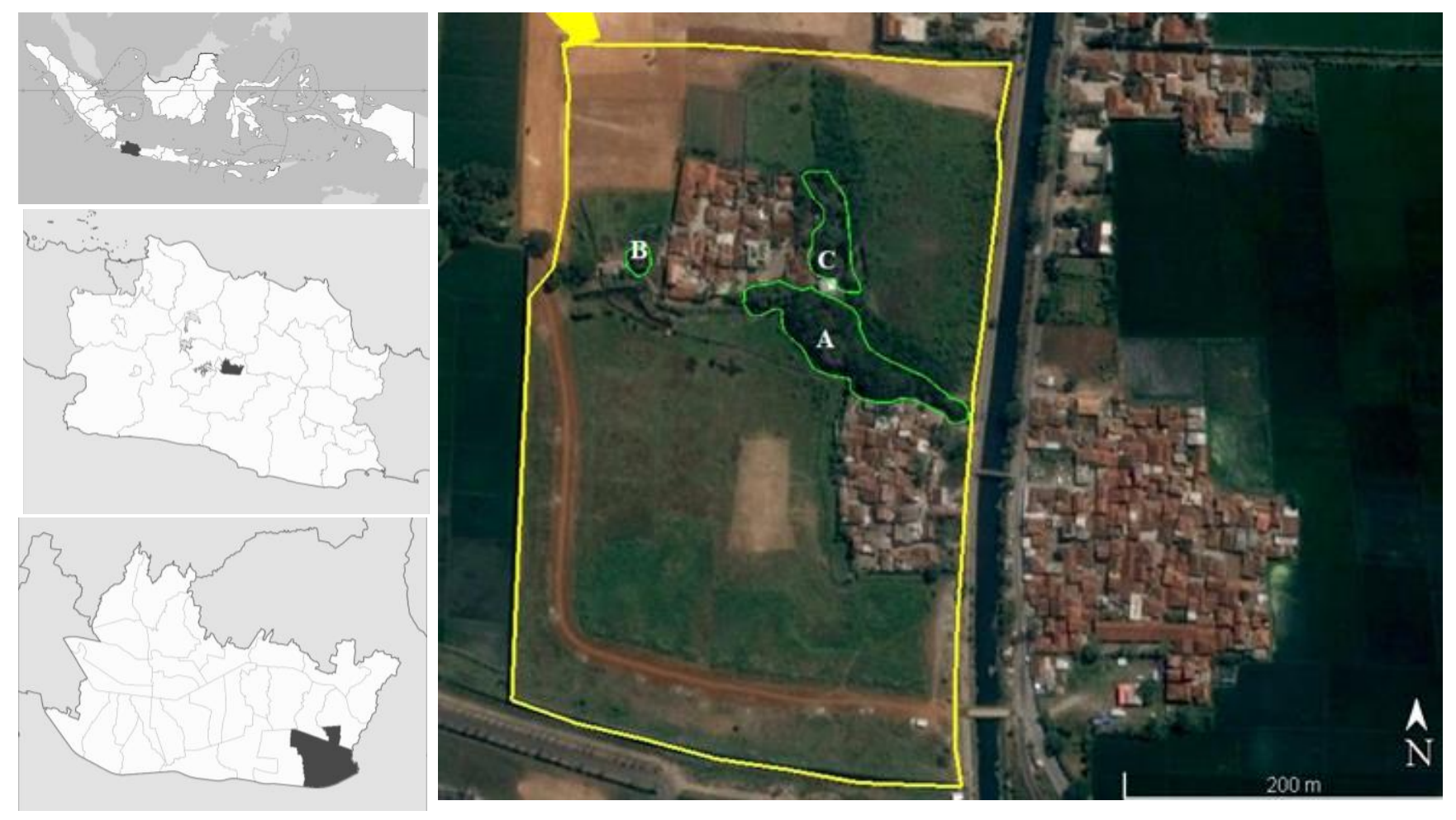

Figure 1. Study area in Babakan Rancabayawak Hamlet, Cisaranten Kidul Village, Gedebage Subdistrict, Bandung City, West Java, Indonesia. Note: yellow line: study area; green line: sampling area to assess the population size 


\section{Nest observation}

Nest counting was carried out on nests that are still actively used by birds. Counting was conducted in three zones, including zone A (southern part), zone B (western part), and zone $\mathrm{C}$ (eastern part) (Figure 2).

\section{Bird's prey}

Data on birds' prey was obtained through semistructured interviews and direct observation. The survey was conducted in the paddy fields around the Summarecon Apartment Settlement and Gelora Bandung Lautan Api (football stadium). The survey was also conducted by observing leftovers under clumps of $B$. vulgaris. The semistructured interview was achieved through the purposive sampling of informants, e.g., farmers and village heads (Ketua $R W$ Babakan Rancabayawak) who were considered to have in-depth knowledge of birds' prey.

\section{Population distribution}

Several procedures need to be performed to determine the distribution of birds, including capturing the birds, installing a mini GPS A8, marking birds using hair color, and morphometrics on the three birds species. Bird catching was done through mist nets. Mist net was made of nylon with a size of $4 \mathrm{~cm} \times 14 \mathrm{~cm} \mathrm{x} 3.5 \mathrm{~m}$ with a total of three bags. Three traps were deployed in the east during 12 hours (05.45 a.m. - 06.00 p.m.) and monitored every two hours. The three captured bird species were identified at the species level. In addition, morphometric measurements were performed, feather coloring to simplify identification, and the installation of a mini GPS.

The A8 mini GPS used had dimensions of $43.2 \times 32 \times$ $13.6 \mathrm{~mm}$, weighs 5 grams, and is integrated on the GSM frequency on the 850/900/1900 Mhz network. The captured birds were GPS-mounted on their backs using tiny bags, and then the birds were released back into their habitat. Within 30 minutes, GPS will send an SMS (Short Messaging System) containing information about the location (google maps link), coordinates, and the remaining GPS battery. We deployed the A8 mini GPS for four days. After that, We caught those birds and removed the GPS.

\section{Data analysis}

Data were analyzed qualitatively. The population size of the birds was analyzed and displayed in the population size estimate (minimum-maximum). The minimum and maximum population size estimates were obtained from the calculation based on the in-out technique. Plant composition and communities, and prey were analyzed descriptively. Information on the distribution of birds is depicted in a map, then analyzed descriptively.

\section{RESULTS AND DISCUSSION}

\section{Population size}

Of 21 days, We used five days to assess the population size. We recorded $B$. ibis has the largest estimated population size compared to other birds, with an average of 1109 individuals (Table 1).
Table 1. Estimation of population size of birds

\begin{tabular}{lccc}
\hline \multirow{2}{*}{ Species } & \multicolumn{3}{c}{ Estimation of population size } \\
\cline { 2 - 4 } & Out & In & Mean \\
\hline Bubulcus ibis & 1087 & 1131 & 1109 \\
Egretta garzetta & 185 & 165 & 175 \\
Ardeola speciosa & 84 & 77 & 81 \\
Subtotal & 1357 & 1374 & 1365 \\
Unidentified & 269 & 361 & 315 \\
Total & 1626 & 1734 & 1680 \\
\hline
\end{tabular}

Ardeola speciosa was recorded with the least estimated population size, with an average of 81 individuals. The $E$. garzetta was recorded with an average of 175 individuals. Therefore, We recorded the total population size of birds is 1680 individuals.

\section{Vegetations of bird's habitat}

The study site consists of several vegetation types, including riparian, shrubs, and home gardens (Table 2). We recorded 60 species of 29 families in the Babakan Rancabayawak. Riparian vegetation in the Rancabayawak River recorded 41 species from 21 families, dominated by Imperata cylindrica. Along the Rancabayawak River, the reforestation area is planted by $B$. vulgaris. This bamboo is deliberately grown by the community, hoping that the plant can be a nest to the birds.

The shrub vegetation consists of 20 species from 14 families. The vegetation is dominated by $M$. pigra and plays an essential role for birds. Mimosa pigra has a height $<2$ meters with peas, inviting other fauna, such as insects or spiders, as one of the birds' prey. Therefore, the existence of $M$. pigra must be maintained or preserved naturally. Based on the observation, $M$. pigra was used as a sleeping site, breeding site, feeding site, and roosting site by $A$. speciosa.

Home garden vegetation consists of 29 species from 18 families. Leucaena leucocephala dominates this vegetation. This species is used as a shelter, roosting, and sleeping site by $B$. ibis, E. garzetta, and A. speciosa. Besides, B. vulgaris, which is also found in the home gardens, is often used as a sleeping, breeding, feeding, roosting, and nesting site of B. ibis, E. garzetta, and A. speciosa. Therefore, L. leucocephala and B. vulgaris are very important for these birds to meet their daily needs.

Based on the calculation, 219 nests were found in zone A, 53 nests were found in zone B, and 57 nests were found in zone $\mathrm{C}$ (Figure 2). Thus, a total of 329 nests was made. During observation, B. ibis, E. garzetta, and A. speciosa tended to make a nest using twigs from L. leucocephala, $B$. vulgaris, $M$. pigra, and sometimes using Cyperus rotundus.

Egretta garzetta prefers higher trees with less shrubby undergrowth because it decreases the disturbance from the human being or other predators from the bottom of trees (Pang et al. 2019). In Faisalabad, Pakistan, cattle egrets were found to build their colonies where the area was not wild and preferably almost near water availability, roadside, and human vicinity (Kour and Sahi 2013; Abdullah et al. 2017). Male cattle egrets establish the breeding territory. The nest was typically built in Acacia 
nilotica and Syzygium cuminii. The nest was made up of rough unlined structures of sticks, reeds, shrubs, and twigs retained in wedges of branches in trees. The cattle egrets started the nest building much before they had a mate. The cattle egrets were seen to collect twigs from the nearby fields, stealing from old nests and collecting from the ground, fallen from other nests (Abdullah et al. 2017).

The biological and ecological behavior of $B$. ibis colonies varies from one region to another, depending on certain intrinsic factors, but mainly by extrinsic factors, such as the availability of water and prey (Mohammedi et al. 2016) and the quality of nest trees for the safety of nests and chicks ( $\mathrm{Si}$ Bachir et al. 2011). In North-Western Algeria, B. ibis nested on three plants such as Ficus elastica, Jacaranda mimosifolia, and Pinus halepensis. Ficus elastica is the most attractive than other trees for cattle egret's breeding. Ficus elastica hosted a larger population than $J$. mimosifolia and even more than $P$. halepensis. This preference may be related to the volume of vegetation cover and probably the foliage that provides covers, and subsequently, security (Mohammedi et al. 2020). The nest's height above the ground affects the breeding success while not influencing the clutch size (Ashoori and Barati 2013). Neb and Selmi (2019) showed that the clutch size and hatching success decreased when the breeding season progressed.

If viewed from the foraging habitat, birds use paddy fields as a place to hunt. The nearest paddy field from Babakan Rancabayawak includes paddy fields around Gelora Bandung Lautan Api/GBLA (football stadium) and residual paddy fields around Summarecon Apartment
Settlement, and paddy fields in Rancanumpang Village Gedebage Subdistrict. Information on the locations of these paddy fields was obtained from community and direct observation.

\section{Birds' prey}

One of the factors that cause birds to abound in a location is the availability of feed or prey. Based on the observation, 19 species were recorded as prey for the Ardeidae birds. Seven of the 19 species were observed through direct observation (Table 3). Generally, $E$. garzetta, B. ibis, and A. speciosa feed on fishes, insects, lizards, snakes, earthworms, frogs, snails, eels, and shrimps. Usually, the leftovers can be found below and between the clumps of $B$. vulgaris and at the foraging places (paddy fields).

The presence of grasses and shrubs was an ideal habitat for insects, allowing abundant prey for E. garzetta (Fadila et al. 2019). Egretta garzetta is popular for its role in biocontrol cattle parasites and land pests. It feeds on a wide range of prey, mainly insects, moths, spiders, frogs, earthworms, and fishes (Shafey 2012), so the cattle egret's role was essential to the farmer (Rezk 2015). On the other hand, B. ibis depends on insects like a housefly, fish, and other invertebrates for food, particularly those that fly after being scared by related large mammals (Kour and Sahi 2012; Jayaratne et al. 2015). Jayaratne et al. (2015) also said that $B$. ibis is considered essential as they feed on the garbage sites of Sri Lanka and control the number of house flies.

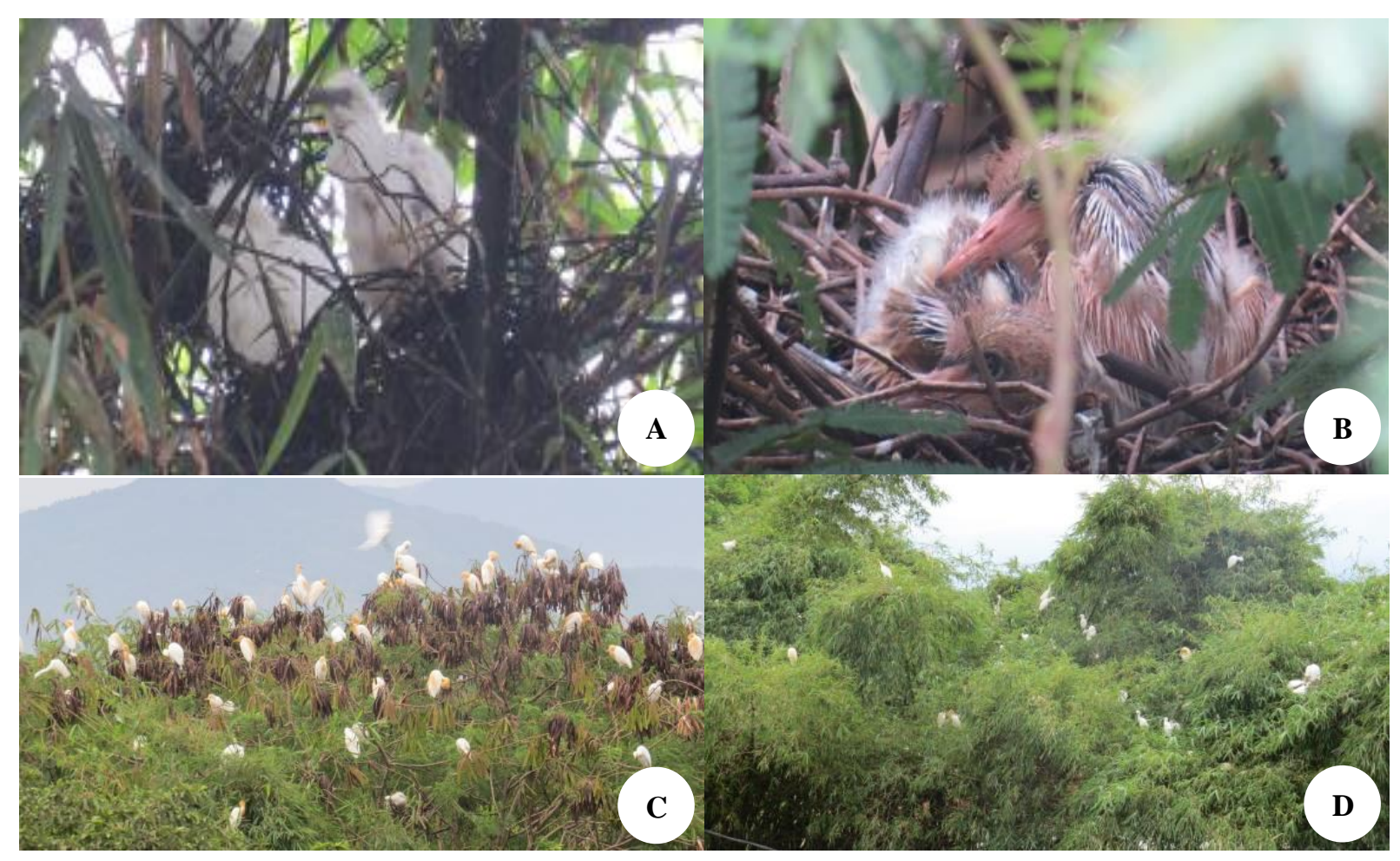

Figure 2. Preference of plants as bird habitat to meet daily needs. A. Nests of Bubulcus ibis in Bambusa vulgaris, B. Nest of Ardeola speciosa in Mimosa pigra, C. Roosting site of Leucaena leucocephala, D. Roosting site in Bambusa vulgaris 
Table 2. Plant composition in Babakan Rancabayawak Hamlet, Bandung City, Indonesia

\begin{tabular}{|c|c|c|c|c|c|}
\hline Family | species & Common name & Local name & Riparian & Shrub & Homegarden \\
\hline \multicolumn{6}{|l|}{ Anacardiaceae } \\
\hline Mangifera indica $\mathrm{L}$. & Mango & Mangga & $\checkmark$ & $\checkmark$ & \\
\hline \multicolumn{6}{|l|}{ Annonaceae } \\
\hline Annona muricata $\mathrm{L}$. & Soursop & Sirsak & & & $\checkmark$ \\
\hline \multicolumn{6}{|l|}{ Araliaceae } \\
\hline Polyscias scutellaria (Burm.f.) Fosberg & Balfour Aralia & Mangkokan & & & $\checkmark$ \\
\hline \multicolumn{6}{|l|}{ Arecaceae } \\
\hline Cocos nucifera $\mathrm{L}$. & Coconut & Kelapa & $\checkmark$ & & $\checkmark$ \\
\hline Cyrtostachys lakka Becc. & Sealing-wax palm & Palem merah & & & $\checkmark$ \\
\hline Acmella paniculata (Wall. ex DC.) R.K.Jansen & Toothache plant & Rumput jotang & $\checkmark$ & & \\
\hline \multicolumn{6}{|l|}{ Asteraceae } \\
\hline Ageratum conyzoides $\mathrm{L}$. & Billygoat-weed & Babadotan & $\checkmark$ & $\checkmark$ & \\
\hline Bidens pilosa $\mathrm{L}$ & Hairy beggarticks & Harega & $\checkmark$ & $\checkmark$ & \\
\hline Crassocephalum crepidioides (Benth.) S.Moore & Redflower ragleaf & Sintrong & $\checkmark$ & $\checkmark$ & \\
\hline Mikania cordata (Burm.f.) B.L.Rob & Heartleaf hempvine & Balakacida & $\checkmark$ & & \\
\hline \multicolumn{6}{|l|}{ Bignoniaceae } \\
\hline Spathodea campanulata P.Beauv. & African tulip tree & Kiacret & & & $\checkmark$ \\
\hline \multicolumn{6}{|l|}{ Cannaceae } \\
\hline Canna indica $\mathrm{L}$. & African arrowroot & Bunga tasbe & $\checkmark$ & $\checkmark$ & \\
\hline \multicolumn{6}{|l|}{ Caricaceae } \\
\hline Carica papaya $\mathrm{L}$. & Papaya & Pepaya & $\checkmark$ & & $\checkmark$ \\
\hline \multicolumn{6}{|l|}{ Combretaceae } \\
\hline Terminalia catappa $\mathrm{L}$. & Sea Almond & Ketapang & $\checkmark$ & & \\
\hline \multicolumn{6}{|l|}{ Convolvulaceae } \\
\hline Ipomoea batatas (L.) Lam. & Sweet potato & Ubi jalar & & $\checkmark$ & \\
\hline \multicolumn{6}{|l|}{ Cypiraceae } \\
\hline Cyperus rotundus $\mathrm{L}$. & Java grass & Rumput teki & $\checkmark$ & $\checkmark$ & \\
\hline \multicolumn{6}{|l|}{ Elaeocarpaceae } \\
\hline Elaeocarpus grandiflorus Sm. & Lily of the valley tree & Anyang anyang & & $\checkmark$ & \\
\hline \multicolumn{6}{|l|}{ Euphorbiaceae } \\
\hline Acalypha siamensis Gagnep. & Tumput & Teh & & & $\checkmark$ \\
\hline Antidesma bunius (L.) Spreng. & Chinese laurel & Buni & & & $\checkmark$ \\
\hline Manihot esculenta Crantz & Bitter cassava & Singkong & $\checkmark$ & & $\checkmark$ \\
\hline \multicolumn{6}{|l|}{ Fabaceae } \\
\hline Gliricidia sepium (Jacq.) Kunth & Madre cacao & Gamal & $\checkmark$ & & $\checkmark$ \\
\hline Leucaena leucocephala (Lam.) de Wit & Wild tamarind & Lantorogung & $\checkmark$ & $\checkmark$ & $\checkmark$ \\
\hline Maniltoa grandiflora (A.Gray) Scheff. & Handkerchief tree & Pohon saputangan & & & $\checkmark$ \\
\hline Mimosa pigra $\mathrm{L}$. & Giant sensitive tree & Rumput garuk & $\checkmark$ & $\checkmark$ & \\
\hline Mimosa pudica $\mathrm{L}$ & Sensitive plant & Putri malu & $\checkmark$ & $\checkmark$ & \\
\hline Paraserianthes falcataria (L.) I.C.Nielsen & Albazia & Albasiah & $\checkmark$ & & $\checkmark$ \\
\hline Parkia speciosa Hassk. & Stink bean & Petai & & $\checkmark$ & $\checkmark$ \\
\hline Samanea saman (Jacq.) Merr. & Rain tree & Trembesi & $\checkmark$ & & \\
\hline Sesbania grandiflora (L.) Poir. & Vegetable hummingbird & Turi & $\checkmark$ & & \\
\hline Gnetaceae & & & & & \\
\hline Gnetum gnemon L. & Gnemon tree & Tangkil & & & $\checkmark$ \\
\hline Lauraceae & & & & & \\
\hline Persea americana Mill. & Avocado & Alpukat & $\checkmark$ & & $\checkmark$ \\
\hline Malvaceae & & & & & \\
\hline Hibiscus macrophyllus (Blume) Oken & Largeleaf rosemallow & Tisuk & & & $\checkmark$ \\
\hline Hibiscus rosa-sinensis $\mathrm{L}$. & China-rose & Bunga sepatu & & & $\checkmark$ \\
\hline Sida rhombifolia L. & Arrowleaf sida & Sidagori & $\checkmark$ & $\checkmark$ & \\
\hline Meliaceae & & & & & \\
\hline Swietenia macrophylla King & Broad-leafed mahogany & Mahoni & $\checkmark$ & & $\checkmark$ \\
\hline Moraceae & & & & & \\
\hline Artocarpus communis J.R.Forst. \& G.Forst. & Breadfruit & Sukun & $\checkmark$ & $\checkmark$ & $\checkmark$ \\
\hline Artocarpus heterophyllus Lam. & Jackfruit & Nangka & $\checkmark$ & $\checkmark$ & $\checkmark$ \\
\hline Muntingiaceae & & & & & \\
\hline Muntingia calabura $\mathrm{L}$. & Malayan cherry & Kersen & & & $\checkmark$ \\
\hline Musaceae & & & & & \\
\hline Musa x paradisiaca var. & Banana & Pisang & $\checkmark$ & & $\checkmark$ \\
\hline Myrtaceae & & & & & \\
\hline Psidium guajava Juss. & Guava & Jambu batu & $\checkmark$ & & $\checkmark$ \\
\hline Syzygium aqueum (Burm.f.) Alston & Water apple & Jambu air & & & $\checkmark$ \\
\hline
\end{tabular}




\begin{tabular}{|c|c|c|c|c|c|}
\hline \multicolumn{6}{|l|}{ Oxalidaceae } \\
\hline Averrhoa carambola $\mathrm{L}$. & Star fruit & Belimbing & & & $\checkmark$ \\
\hline Oxalis corniculata $\mathrm{L}$. & Yellow wood sorrel & Calincing & & $\checkmark$ & \\
\hline \multicolumn{6}{|l|}{ Poaceae } \\
\hline Bambusa vulgaris Nees & Common bamboo & Bambu haur hijau & $\checkmark$ & & $\checkmark$ \\
\hline Chrysopogon zizanioides (L.) Roberty & Vetivergrass & Akar wangi & $\checkmark$ & & \\
\hline Cymbopogon citratus (DC.) Stapf & Lemon grass & Serai & $\checkmark$ & & \\
\hline Imperata cylindrica (L.) P.Beauv. & Cogongrass & Alang-alang & $\checkmark$ & $\checkmark$ & \\
\hline Leersia hexandra $\mathrm{Sw}$. & Southern cutgrass & Kilameta & $\checkmark$ & & \\
\hline Pennisetum purpureum Schumach. & Elephant grass & Rumput gajah & $\checkmark$ & & \\
\hline Saccharum arundinaceum Retz. & Hardy sugar cane & Tebu & $\checkmark$ & & $\checkmark$ \\
\hline \multicolumn{6}{|l|}{ Rubiaceae } \\
\hline Hedyotis corymbosa (L.) Lam. & Two-flowered Oldenlandia & Rumput mutiara & $\checkmark$ & $\checkmark$ & \\
\hline \multicolumn{6}{|l|}{ Sapindaceae } \\
\hline Dimocarpus longan Lour. & Longan & Lengkeng & & & $\checkmark$ \\
\hline Filicium decipiens (Wi\& Arn.) Thwaites & Fern tree & Kisabun & $\checkmark$ & & \\
\hline \multicolumn{6}{|l|}{ Solanaceae } \\
\hline Capsicum annuum $\mathrm{L}$. & Cayenne pepper & Cabai & $\checkmark$ & & \\
\hline Solanum melongena $\mathrm{L}$. & Eggplant & Terong & $\checkmark$ & & \\
\hline Solanum torvum $\mathrm{Sw}$. & Turkey berry & Tekokak & & $\checkmark$ & \\
\hline \multicolumn{6}{|l|}{ Verbenaceae } \\
\hline Lantana camara $\mathrm{L}$. & Shrub verbena & Saliara & $\checkmark$ & & \\
\hline Stachytarpheta jamaicensis (L.) Vahl & Blue porter weed & Pecut kuda & $\checkmark$ & $\checkmark$ & \\
\hline \multicolumn{6}{|l|}{ Zingiberaceae } \\
\hline Costus megalobrachtea K.Schum & Costus & Pacing & $\checkmark$ & & \\
\hline Etlingera elatior (Jack) R.M.Sm. & Painted net leaf & Honje & $\checkmark$ & & \\
\hline
\end{tabular}

Table 3. Birds' prey in Babakan Rancabayawak, Bandung City, Indonesia

\begin{tabular}{|c|c|c|c|}
\hline Local name & Common name & Taxa & Data types \\
\hline Ikan emas & Common carp fish & Cyprinidae & $\mathrm{O}$ \\
\hline Ikan nila & Nile tilapia & Cyprinidae & $\mathrm{O}$ \\
\hline Katak & Frog & Anura & $\mathrm{O}$ \\
\hline Capung & Dragonfly & Odonata & $\mathrm{O}$ \\
\hline Kepiting sawah & Freshwater crab & Gecarcinucoidea & $\mathrm{O}$ \\
\hline Ular & Snake & Squamata & $\mathrm{O}$ \\
\hline Belut & Eel & Synbranchidae & I \\
\hline Remis & Mussels & Veneridae & I \\
\hline Keong sawah & Freshwater snail & Ampullariidae & I \\
\hline Kasir & Cricket & Gryllidae & I \\
\hline Laba-laba & Spider & Arachnida & I \\
\hline Belalang & Grasshopper & Orthoptera & I \\
\hline Udang & Shrimp & Crustacea & I \\
\hline Ikan beunteur & Rasbora fish & Cyprinidae & I \\
\hline Ikan tampele & Betta fish & Cyprinidae & I \\
\hline Kecebong & Tadpole & Amphibians & I \\
\hline Cacing & Earthworm & Haplotaxids & I \\
\hline Orong-orong & Asian grass lizard & Squamata & I \\
\hline Kadal & Lizard & Squamata & $\mathrm{O}$ \\
\hline
\end{tabular}

Notes: O: Observation; I: Interview; Source: Primary Data (2018)

\section{Distribution}

Based on the tracking using GPS mini A8, B. ibis tends to move towards the east and south by the radius of 1-12 $\mathrm{km}$. Egretta garzetta tends to move northwards with a radius of 1-2 km. Ardeola speciosa was traced to move south with a radius of movement of less than $1 \mathrm{~km}$ (Figure 3). Based on direct observation, the birds also move from all four cardinal winds.

Based on the distribution map of the birds, it can be seen that these birds are found in the green area. Green area is identified as paddy fields, ponds, settlements, industries, and vacant or unused land. The paddy field is found dominant in the eastern and southern area of Babakan Rancabayawak Village as one of the factors influencing the distribution of the Ardeidae. Those areas are referred to the Rancaekek, Majalaya, and Solokan Jeruk. Pinto et al. (2013) stated that land cover affects the displacement and habitat use of Ardeidae, such as Ardea alba, Ardea cocoi, and B. ibis. Therefore, We assume that the movement of birds is influenced by the source of foraging, in this study, the paddy field. 


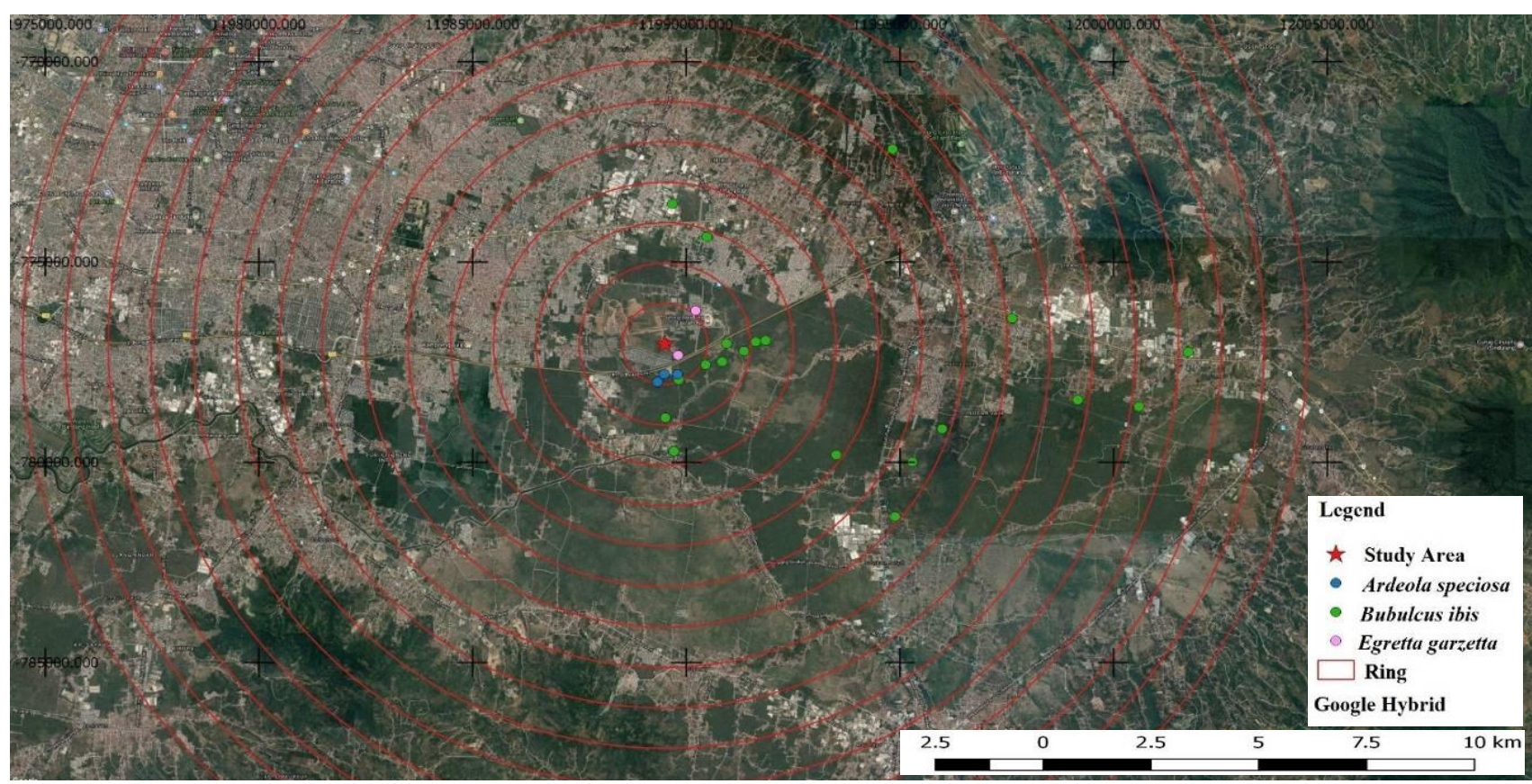

Figure 3. Distribution of Bubulcus ibis, Egretta garzetta, and Ardeola speciosa in West Java, Indonesia

The farthest radius of distribution from Babakan Rancabayawak is $12 \mathrm{~km}$. In general, birds of the Ardeidae can explore various wetland habitats (Pinto et al. 2013). Most of the wetlands within a radius of $12 \mathrm{~km}$ from Babakan Rancabayawak are paddy fields in the Rancaekek, Majalaya, and Ciparay. Therefore, We assume that the paddy fields in these areas are essential habitats for Ardeidae birds to meet their daily needs.

We conclude that B. ibis, E. garzetta, and A. speciosa will still survive in the Babakan Rancabayawak, Gedebage Subdistrict. Bambusa vulgaris, L. leucocephala, and M. pigra are plants that are used as perching and nesting sites by B. ibis, E. garzetta, and A. speciosa. The estimated population mean of those birds was 630 individuals, 92 individuals, and 43 individuals, respectively, with the population average of those birds, is 1680 individuals. The number of birds' nests is 329 nests. Based on distribution mapping, birds moved east and south, covering paddy fields in Rancaekek, Solokanjeruk, and Majalaya within a radius of $12 \mathrm{~km}$. Management effort can be conducted by not cutting down the plants that become nesting and perching sites and maintaining the wetlands in their habitats.

\section{ACKNOWLEDGMENTS}

Acknowledgments were given to the CESS and the expertise that has supported this study. We are grateful to Summarecon Bandung, Ornithology Division, Biology Student Association (Himpunan Mahasiswa Biologi), Universitas Padjadjaran and surveyor team. Also, thanks to the local community in Babakan Rancabayawak Hamlet.

\section{REFERENCES}

Abdullah M, Khan RA, Rafay M, Hussain T, Ruby T, Rehman F, Khalil S, Akhtar S. 2017. Habitat ecology and breeding performance of cattle egret (Bubulcus ibis) in Faisalabad, Pakistan. Pakistan J Zool 49 (5): 1863-1870. DOI: 10.17582/journal.pjz/2017.49.5.1863.1870.

Ashoori A, Barati A. 2013. Breeding success of Ardeids (Black-crowned night heron, little egret and cattle egret) in Southern Caspian Sea. Ital J Zool 80 (1): 149-145. DOI: 10.1080/11250003.2012.758784.

Bibby CJ, Burgess ND, Hill DA. 1992. Bird Cencuses Techniques. Academic Press Limited, London.

Dias RA, Blanco DE, Goijman AP, Zaccagnini ME. 2014. Density, habitat use, and opportunities for conservation of shorebirds in rice fields in Southeastern South America. Condor: Ornithol Appl 116 (3): 384-393. DOI: 10.1650/CONDOR-13-160.1.

Fadila MI, Mardiastuti A, Mulyani YA. 2019. Insects as food source for cattle egret (Bubulcus ibis) in Jatibarang Landfill, Semarang. IOP Conf Ser Earth Environ Sci 528: 1-7. DOI: 10.1088/17551315/528/1/012016.

Harisa MN. 2016. Assessment of status, diversity, and threat of wetland birds of Bathi Lake, Doddabati Village, Davanagere District, Karnataka, India. J Entomol Zool Stud 4 (4): 586-590.

Howes J, Bakewell D, Noor YR. 2003. Guide of Shorebird. Wetlands International-Indonesia Programme, Bogor. [Indonesian]

Iskandar J, Iskandar BS. 2020. The effect of the partial solar eclipse on behavior of three species of Ardeidae in Rancabayawak Bandung. Biodjati 5 (2): 316-328. DOI: 10.15575/biodjati.v5i2.4578.

Iskandar J. 2017. Ornitologi dan Ethnobiologi. Plantaxia, Yogyakarta. [Indonesian]

Jayaratne RL, Perera IC, Weerakoon DW, Kotagama SW. 2015. Cattle egrets (Bubulcus ibis) control the population of house flies (Musca domestica) in garbage dumping sites: A comparison between two garbage dumping sites, Kandy, Sri Lanka. Proceedings of the International Forestry and Environment Symposium 2015 of the Department of Forestry and Environmental Science, University of Sri Jayewardenepura, Sri Lanka. DOI: 10.31357/fesympo.v20i0.2530.

Kazantzidis S, Yfantis G, Poirazidis K. 2013. Factors influencing species composition and nest abundance of heron colonies. J Biol Res Thessalon 20 (1): 276 - 289.

Kour DN, Sahi DN. 2012. Studies on the community ecology of cattle egrets Bubulcus ibis coromandus (Boddaert) in Jammu (Jammu and Kashmir), India. Intl J Biodivers Conserv 4 (13): 439-445. DOI: 10.5897/IJBC11.105. 
Kour DN, Sahi DN. 2013. Aspects of breeding biology of cattle egret, bubulcus ibis coromandus (boddaert) in Jammu, India. Intl J Environ Sci 3 (5): 1547-1561. DOI: 10.5897/IJBC11.105.

Li X, Xian Z, Xinrong X, Shicheng L, Yongqiang Z, Danxi C, Chenxi H, Bingyao C, Guang, Y. 2016. Bird diversity in the buffer zone of the largest coastal nature reserve of China and conservation implications. Pakistan J Zool 48 (4): 1193-1199.

Lin W, Cen J, Xu D, Du S, Gao J. 2018. Wetland landscape pattern changes over a period development (1985-2015) in the Zhoushan Islands of Zhejiang Province, China. Estuar Coast Shelf Sci 213: 148159. DOI: 10.1016/j.ecss.2018.08.024.

MacKinnon J, Phillips K, Balen BV. 1992. Birds in Sumatera, Java, Bali, and Kalimantan. LIPI/Bird Life, Bogor. [Indonesian]

Mohammedi A, Doumandji S, Ababou A, Koudjil M, Rouabhi A. 2016. Impact of predation by cattle egret Bubulcus ibis L. on wildlife of farmlands in Chlef Region (Algeria). Leban Sc J 17 (2): 117-129. DOI: 10.22453/LSJ-017.2.117129.

Mohammedi A, Kouidri M, Mahmoudi A, Ababou A. 2020. Ecological and biological behavior of nesting colony of Bubulcus ibis in NorthWestern Algeria. Leban Sci J 21 (1): 1-11. DOI: 10.22453/LSJ021.1.001-011.
Neb A, Selmi S. 2019. Nesting parameters of the little egret (Egretta garzetta) in Boughrara Lagoon, Southeastern Tunisia. Waterbirds 42 (3): 328-332. DOI: 10.1675/063.042.0309.

Pang RH, Yu TL, Busam M. 2019. Low breeding success of the little egret (Egretta garzetta) near residential areas and in colonies exposed to gales: A comparison of colony in Sichuan, Southwest China, with literature. Anim Cells Syst 23 (3): 235-240. DOI: 10.1080/19768354.2019.1596980.

Pinto DP, Chivittz CC, Bergmann FB, Tozetti AM. 2013. Microhabitat use by three species of egret (Pelecaniformes, Ardeidae) in Southern Brazil. Braz J Biol 73 (4): 791-796. DOI: 10.1590/S151969842013000400015 .

Rezk HM. 2015. Anatomical investigation on the appendicular skeleton of the cattle egret (Bubulcus ibis). J Exp Clin Anat 14 (1): 5-12. DOI: 10.4103/1596-2393.158919.

Shafey H. 2012. Desportesius invaginatus (Linstow, 1901) Chabaud and E. Campana, 1949 (Nematoda, Acuariidae) from Ardeola ibis ibis with reference to the fine structure of the cordons. PUJ 5 (1): 49-57.

Si Bachir A, Ferrah F, Barbraud C, Céréghino R, Santoul F. 2011. The recent expansion of an avian invasive species (the cattle egret Ardea ibis) in Algeria. J Arid Environ 75 (11): 1232-1236. DOI: 10.1016/j.jaridenv.2011.04.021. 